\title{
Uma Perspectiva Cognitiva Sobre o Design de Artefatos Digitais Educacionais.
}

\author{
Gabriela Trindade Perry \\ Orientador: Fernando Schnaid \\ Data da defesa: 16/08/2010
}

No sistema produtivo contemporâneo, o design é uma atividade central, pois responde pelo projeto de bens e serviços. Design não está, todavia, relacionado apenas com as capacidades criativas ou com leituras estéticas do projetista - como faz crer o uso popular da palavra - englobando profissionais dos mais diversos domínios. Um engenheiro eletrônico que projeta circuitos; um engenheiro mecânico que projeta motores; um arquiteto que projeta um edifício; um designer gráfico que projeta uma marca; um analista que projeta um software: todos são designers. Em comum estes profissionais têm o mesmo tipo de problema, e assim o percurso cognitivo destes profissionais é similar. Da mesma forma, espera-se que um designer que projeta um artefato educacional digital também apresente comportamentos semelhantes durante o processo de projeto. Todavia, como é regra para a atividade de design, o projeto de artefato educacionais digitais tem seus desafios. Neste caso específico, o desafio do designer está no fato de que ele não pode projetar sozinho. Até mesmo nas etapas iniciais do projeto - quando se está gerando idéias e explorando conceitos, quando não se tem clara a forma ou mesmo a estrutura do artefato - o designer não pode projetar sozinho. Isto porque, para este tipo de artefato, o conhecimento e as habilidades do designer precisam ser orientadas por educadores e especialistas no domínio. Neste cenário se colocam as questões de pesquisa desta tese, que buscam compreender qual papel o designer tem enquanto membro de uma equipe de desenvolvimento de artefatos digitais educacionais. Como ele constrói o espaço do problema? Que estratégias ele utiliza quando não tem conhecimentos para projetar sozinho? Como os domínios do design e da educação se cruzam e se sobrepõe? Utilizando métodos adaptados à análise de atividades de design, investigou-se a atividade de duas duplas - formadas por um designer e por um educador especialista no domínio - buscando regularidades que pudessem responder às questões da tese. Os resultados sugerem que a complexidade do tema (química) não é um fator tão marcante para a qualidade do projeto quanto a estratégia utilizada pelo designer. Quando o designer decidiu tentar brifar seu colega - a fim de estruturar seu conhecimento sobre o tema para embasar o projeto - o efeito da complexidade do tema se fez sentir. Já quando o designer buscou integrar rapidamente as informações recebidas de seu colega educador ao projeto - sem antes buscar estruturar seu conhecimento sobre o tema - o efeito do tema foi tênue. Nenhuma destas estratégias corresponde à descrição de processos de design reportadas na literatura. Ao utilizar a estratégia de integrar o mais rápido possível, o designer deixou claras algumas de suas concepções a respeito dos processos de ensino e aprendizagem; teorias implícitas provavelmente construídas durante sua exposição à educação formal. Ao usar a estratégia estruturar para depois projetar, o designer não demonstrou identificar implicações e potenciais estruturais da orientação teórica seguida pelo seu colega. Estes resultados podem fundamentar uma discussão a respeito da necessidade da atenção à formação de designers para trabalhar no projeto de artefatos digitais educacionais.

Palavras-chave: Cognição em Design. Design de interfaces. Artefatos Digitais Educacionais. 